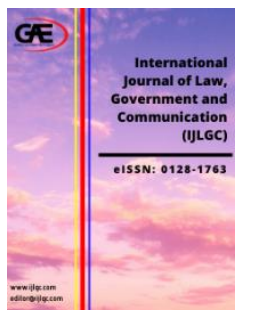

INTERNATIONAL JOURNAL OF LAW, GOVERNMENT AND COMMUNICATION (IJLGC)

WWW.ijlgc.com

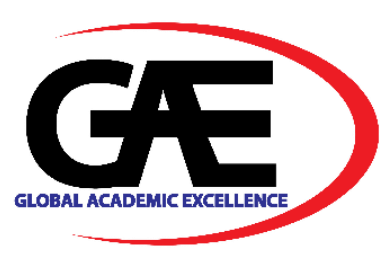

\title{
FORM AND FUNCTION OF PENDHAPA (TRADITIONAL JAVANESE HALL) IN JAVANESE SOCIETY
}

\author{
Tri Prasetyo Utomo ${ }^{1}$, Bani Sudardi ${ }^{*}$, Wakit Abdullah $^{3}$, Nanang Rizali Sardjono ${ }^{4}$ \\ 1 Student of Cultural Studies Department, Postgraduate, Universitas Sebelas Maret \\ Email: triprass@yahoo.com \\ 2 Professor of Cultural Studies Department, Postgraduate, Universitas Sebelas Maret \\ Email: banisudardi@yahoo.co.id \\ 3 Professor of Cultural Studies Department, Postgraduate, Universitas Sebelas Maret \\ Email: abdullahwakit@yahoo.com \\ $4 \quad$ Universitas Muhammadiyah Bandung \\ Email: nangriz@yahoo.com \\ * Corresponding Author
}

\section{Article Info:}

Article history:

Received date: 10.10 .2017

Revised date: 20.11.2017

Accepted date: 30.10 .2021

Published date: 01.12.2021

\section{To cite this document:}

Utomo, T. P., Sudardi, B., Abdullah, W., \& Sardjono, N. R. (2021). Form And Function Of Pendhapa (Traditional Javanese Hall) In Javanese Society. International Journal of Law, Government and Communication, 6 (26), 13-22.

DOI: $10.35631 /$ IJLGC.626002.

This work is licensed under CC BY 4.0

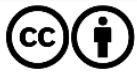

\section{Abstract:}

Pendhapa in this paper is a traditional Javanese hall. The form and function of Pendhapa have a characteristic. The discussion of Pendhapa in this paper is more emphasis on form and function in building communication in the Javanese people. It shows the form and functions of the pendhapa. The method of this research is qualitative research. We use observation, in-depth interviews, and content analysis. The research found that pendhapa generally shaped Joglo, and is the only house that is owned by noble persons. Joglo is in the square a with four-poster as the main pillar. The four pillars support the roof towering in the middle. The main pillar in the Joglo house is often called Saka Guru. And the roof in the middle of the Joglo house is called the roof Brunjung. Pendhapa initially serves as a gathering place and deliberation. Pendhapa is the place of social interaction between citizens to know each other. In traditional Javanese houses, Pendhapa is often called a front home and serves as a living room. Pendhapa is often also called an open room or public room. However, in its development Pendhapa can function as a social communication space or can also be called social communication media. It is associated with the development of the culture and lifestyle of the people in the open society.

Keywords:

Pendhapa, Form, Function And Media 


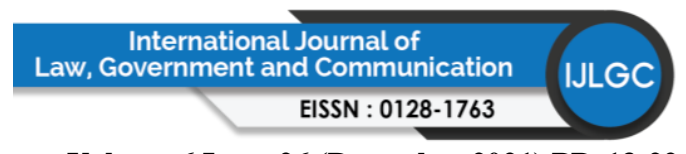

Volume 6 Issue 26 (December 2021) PP. 13-22

DOI 10.35631/IJLGC.626002

\section{Introduction}

Pendhapa generally formed Joglo, and is the only house that is owned by the noble persons. Joglo square and four-poster as the main pillar is often called Saka Guru. The four pillars support the roof towering in the middle is called the roof Brunjung, The slope of the roof is sharper than the pyramid roof. On development, Pendhapa formed Joglo house has undergone many changes, so it has diverse forms. Here is some form of Pendhapa JogJo: Pendhapa home 'Joglo' is building the house. Traditional Java has the most complex formed. Basically pendhapa home 'Joglo' square four and only four-poster called 'saka Guru', So just a form of the middle course of form Home 'Joglo' growing up now. Subsequent developments occur additions to parts of the skies so that the pules increases according to the needs. Pendhapa home 'Joglo' is a form of Javanese traditional house that has full-loaded most ideal for use as a meeting room. Judging from the structure of the building, houses 'Joglo' also has a more complete structure compared with other forms of Javanese Traditional Home. Houses 'Joglo' has a shape that is very flexible, because if you want to expand the space can be done simply by adding a 'porch ${ }^{1}$ around him, so that the poles and the structure became increasingly complete. Houses 'Joglo' is a building that has a comprehensive plan space. Houses 'Joglo' is used as 'Pendapa' which serves as a meeting place and a place deliberation. So the house 'Joglo' is only one form of various forms of traditional Javanese house. Houses Joglo "has a roof towering in the middle. which is referred to as the roof Brunjung. The roof is on the bottom is supported by four pillars called Saka Guru. Roofs 'Brunjung' in house 'Joglo' has the same shape on the sides facing each other, but in the front-rear side has a different shape to the left and rigbi side. On the irom-rear side of the trapezoid-shaped roof, while the left and right side of the triangular tapered top. Roofs 'Brunjung' in house 'Joglo' has a different shape when compared with be roof 'Brunjung' in house 'Limasan' and House Tajug. At Home 'Joglo' shape of the roof "Brunjung' higher and has a roof slope sharper flan the roof 'Brunjung' in house 'Limasan, While the roof 'Brunjung' in house Tajug' has four equal sides are triangular shaped tapered top and have fee same inclination angle with the roof Brunjung in house Joglo.

In addition to the roof 'Brunjung', forms the roof'Joglo' has several different layers of roof slope angle between the shape of each other. In ihe second tier under the roof Brunjung is called the roof 'Responder' with a slope angle of the sloping roof over the angle of the roof Brunjung'. In the third and fourth tier respectively called the roof Penitih and Peningrat. Both forms the roof of the same has a-more gentle shape of the roof compared to the slope of the roof 'Responder ${ }^{1}$ and roof 'Brunjung'. House roof shape 'Joglo' has several types based on their shape and the number of types of the roof of which form two-layered, three-layered or four layers. The more layers in the form of the roof, the more complete and perfect form of house 'Joglo' is. Type houses Joglo which has the form of a coated roofi four Houses 'Jogio* the most perfect types, such as Houses 'Joglo Stoom damp' and House 'Joglo Hageng'. An example is 'Pendhapa Court' Pura Mangkunegaran which is a type of house 'Joglo Hageng'. 


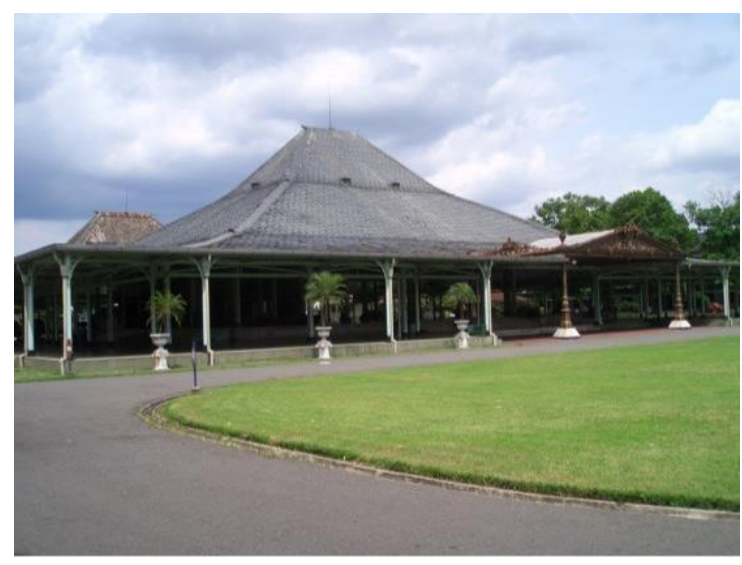

Bentuk 'Pendapa Agung' Pura Mangkunegaran Surakarta

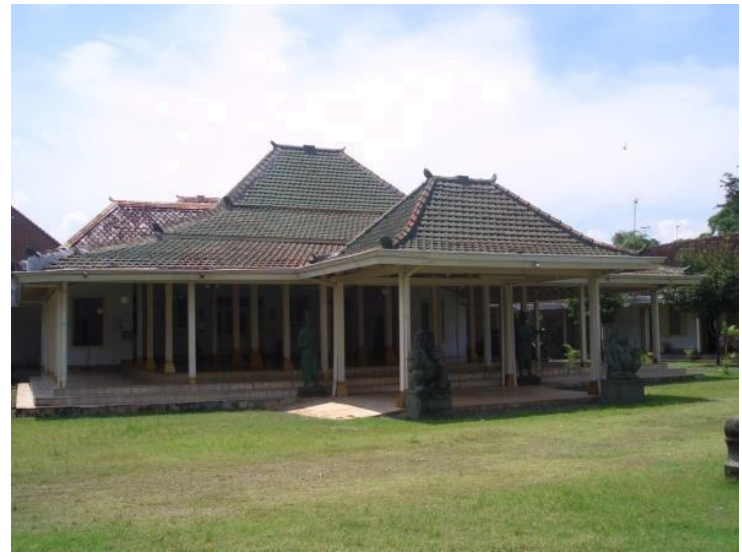

\section{Bentuk 'Pendhapa Dalem Suryohamijayan' Surakarta.}

Pendhapa was the home front that point to receive guests, breaks or other purposes, but not a place to stay (family bed). In general, Pendhapa always open meaning there was partitioned space. Home front or Pendhapa must pemidangan beam with a length of rodents, reduced the number of number is a multiple of 5 (five) remain 2 (two). For example, beam 17 feet long, was reduced $3 \times 5=2$ feet; pemidangan rodents 12 feet minus $2 \times 5=2$ feet. All the numbers were reduced multiples of 5 (five) remain 2 (two) called a 12-foot fell designation Kitri called home. Home fiont or pendhapa should measure falls Kitri. Pendhapa is radiant cultural values of ethnic Javanese. His is evident in its physical manifestation, such as the shape, the structure and the decoration. Pendhapa physical form, ia addition to paying attention to the aesthetic values, are also bound by the cultural values prevailing in the Java community. Spatial systems always refer to the non-physical aspects that customs and beliefs that they profess. Therefore, pendaapa can blend with the natural environment and culture of the people. Uniqueness always appear on pendhapa, for example: the symmetrical shape of the building, roof shape and Lirnasan Joglo, has the main poles, has a lacade and a different side and facing south. Pendhapa is a building in the Java architecture located on the front.

Pendhapa building adjacent to Pringgitan and Griya Ageng. Pendhapa function is as a living room, interact with others, as well as a gathering place and deliberation. The shape and setting 


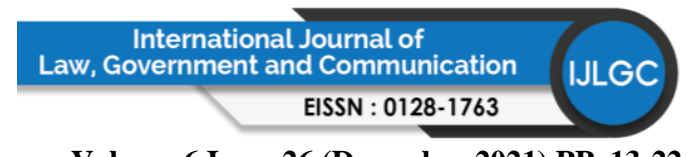

Volume 6 Issue 26 (December 2021) PP. 13-22

DOI 10.35631/IJLGC.626002

of the building that symbolizes pendhapa meaning of harmony between the occupants and the surrounding community. The aims of the research are to describe the form and function of pendhapa as a kind of Javanese hall. In the traditional era, pendhapa has specific function as public area and part of living house of a noble man. But, today the form and the function had changed. It is the main aims of our research.

\section{The Method}

The research is qualitative research. The main aims is to describe change of form and functions of Javanese hall called pendhapa. The location is in Surakarta, Central Jaca as the heart of Javanese culture. The research time is during 2000-2017. There are three source of data, namely the artefact, informant, and written material as book, magazine, article, journal, and so on. To the artefact we observed well and take same photos. We are in depth interview to the informant, dan do content analysis to the written materials. At the end of the research we try to describe the aims.

\section{Literary Studies}

Javanese cutaral life in the city of Surakarta is a Javanese civilization rooted in the Kingdom. This civilization has a history of literature that has been there since four centuries ago, and has the art developed in ttte form of dance and sound art Kraton, and characterized by a religious life that is highly syncretistic, a mixture of elements of Hinduism, Buddhism, and Islam. This is especially true in the city of Surafcarta, who developed into dozens of contemporary religious movement, called As movement psychotherapy. Regional palaces of Java is called Negarigtmg (Koenfjaraningraf, 1984: 25. Javanese culture centered on the Mataram kingdom before it breaks into Kraton Surakarta. Given that in Central Java of yore is a cultural center that is the palace, the Surakarta in Bother discussion is considered to represent Central Java, it is based on the premise of the palace as a cultural center for the surrounding community. Culture that grew up in the surrounding regions, basically strongly influenced by the culture palace. Javanese way of life is inseparable from the role of King and power in the Kingdom. Given the position of the Palace as the center of the universe, then setting the buildings within the palace can not be separated from efforts to harmonize the Site of the king Kraton community with the universe. Position cannot be separated front the power authority has, also related to the spiritual concept which is presumably due to the influence of Indian center (Darsiti, 1989: 3). Traditional culture is BO longer a social states symbol, to anyone who could took away her economically, socially, and intellectually can be part of a noble culture. There is also a new pattern in the traditional art of professionalism. Apprenticeship in artistic inheritance pattern is replaced with the institutions of art. Formalism old palace of culture was replaced by formalism plural of the institutions of art (Kuntowijoyo, 1987:29).

Human life in the cultural environment of Java, basically stated on the basis of four areas or scope of the belief, that confidence, social, personal egression (personality) and problems or meaning. The four will affect the pattern of thought, action and his work. In terms of work, in which applies where the artificial environment or place of residence or work of architecture as part of the cultural life (Arya Ronald, 2005: 3). The settlements in the urban concept of Java is an extension of the palace to the region Negari Dalem Agung. There are some of the terminology used to describe a place to stay. The concept of territory Dalem means a world 


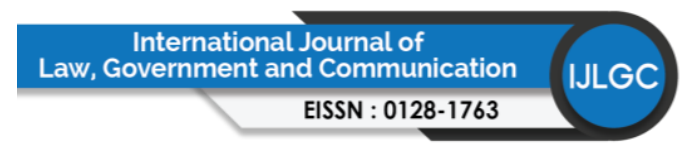

Volume 6 Issue 26 (December 2021) PP. 13-22 DOI 10.35631/IJLGC.626002

where the family originated. Physically called dwelling or place of residence of the Javanese in Dalem terminology that is inside the fence where ttte house was buih. Omah own words Human close to understanding the ancient Javanese language means the floor is liveable. This means that in Javanese culture, the concept of the house was not referring solely to the physical building, but within the person and his family lived, $\mathrm{ft}$ is not permanent in the house may be closely associated with the idea of a place to stay as a home, not a building. Social cohesion which give a sense of security and territoriality pages recognized by the community as its Dalem is the main structure of the residential concept (A. Good P. Wiryomartono, 1995:60).

In the Java community, the arrangement of the house within a family consists of several houses. In addition to special homes for shelter (bed) family, no home of its own as Pendhapa for hearings or receive guests. Home to the family bed (Dalem) is called back home, while pendhapa called home front. Among the house back and front of the house there is a home interlace called Peringgitan derived from the word meaning Anggit Ringgit or puppet. The house is usually to hold puppet shows, while the audience sits in pendhapa or home front The house is one of culture. Cultural development of the past v«ry nature lOatori centric, so that the house in the residential area or neighborhood (Kraton) family can not be separated from the provision of the palace. The meaning of the provisions of the court does not mean the shape and structure of the house on their families and most people have to mimic the shape and composition of the court, even on the contrary, there is a ban mimic certain home arrangement \{Fibre Kawruh Kalang, Pethikan Griya Jawi: 79). Java home building structure is an arrangement of spaces that reflect the distinctive buildings such as: pendaapa, Peringgitan, Dalem. Pavvon. Gaiidbok. and Cadri. Relation between this arrangement is an arrangement of space / building process of its realization highly influenced by mythology and cosmology Java (Suhardi, 2004:28).

Java House manifestation is a manifestation of a way of TKEA (trust, knowledge, ethics and aesthetics) Javanese, it is as the elaboration of the concept of the relationship between humans Java with its natural surroundings. Basically Java architecture consists of five kinds of shapes, and front views each have a symmetrical shape. The concept of building pendhapa more laid benchmark on nature, environment, people, culture and cosmology that they profess. Meanwhile, one very important factor in the design of buildings pendhapa is the scale and size of the building. The unit of measure used in buildings pendhapa in different Java architecture with buildings pendhapa thriving today. Bangunann pendhapa in Java architecture using a unit of measure that is derived from human limbs Java, such as asta (arm), halibut (foot), Tebah (width of the palm of the hand), span (the distance between the tip of the thumb to the little finger when the hand is stretched ) and so forth. The use of human scale like this can produce works of building design is more reasonable and consistent with the physical needs of people's daily life of its inhabitants. Units in the building pendhapa rather refers to the natural and human environment. In the design of buildings pendhapa, appear to have the maturity of the design of integrating the elements of culture with aesthetic elements. The elements in question represents the union between the transcendental element of trust in the context of cosmology. Thus there are elements that are contrary to the concepts of trust, such as the look of the building, the direction / orientation of the building, the architecture, system layout and the structure and construction of the building. View from the front view and a side vfew of the 


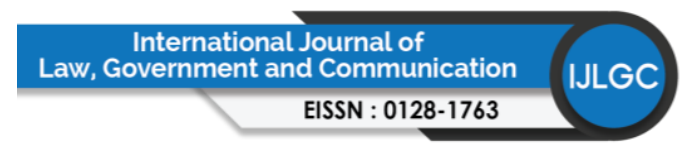

Volume 6 Issue 26 (December 2021) PP. 13-22 DOI 10.35631/IJLGC.626002

building, seen (hat it shows kesetangkupan Building Java \{symmetry) on each pere judannya. Meanwhile, when building Java viewed from the front it can be recognized by their kiwa section (left) and section tengen (right), Kiwa section is part of the building which is located on the left side direction toward the occupant, as docs tengen section (right). Both pans are no different from those commonly known as a side of the building, as is the case with ngajeng parts (front! and part wtngking (rear) which has elements similar construction. In other words, part-wingking ngajeng buildings, many associated with the direction of building Java pamanjang; while part-tengen kiwa associated with panyelak direction. (Josef Prijoiomo. 1995: 25)

In the present values developed in the community more diverse and open (open society). In such societies, diversity of values caused by the growing needs of an increasingly diverse members of society as well. The values of a diverse society provide an opportunity to the changing values of Javanese culture. Likewise, functionality and value pendhapa ihat developed in diverse and open society like this are likely to undergo change and development. Therefore, based on the development needs of the community at the present time, there is also a change in the function and value pcixlhapa in Java architecture.

\section{The Discuss}

Building Pendhapa rectangular-shaped floor plan and has the main pillars in the middle of the room. In its development, Pendhapa experiencing widening by adding pillars supporting its edges in accordance with the needs of the space. In addition, the expansion Pendhapa also done by expanding toward the four sides to form a lobby called overhang. Therefore, Pendhapa can be used as a meeting room or space where deliberation among citizens in the surrounding community. In the development of the cultural community, Pendhapa also functioned as a commercial space. In the Java community, spatial concepts in Java Architect consists of several spatial arrangement. Besides Griya Ageng/Dalem, as a family residence, There is also a front room called Pandhapa which serves as a reception room. The space serves as a family room called Griya Ageng/Dalem or Omah mburi (back home\}, while the space used as a living room or Pendhapa called Omah ngarep (front of house). Among the house back and front of the house there is space interface called

Pringgitan. Pringgitan word comes from the word ringgit means puppet. Pringgitan generally serves as a venue for staging puppet. Puppet audience directly in Pendhapa is space generally consists of men. While the Wayang shadow can be seen from space Dalem is usually done by women.

Javanese cultural life in the city of Surakarta is a Javanese civilization rooted in the Kingdom. This civilization has a history of literature that has been there since four centuries ago, and has the art developed in the form of dance and sound art Kraton, and marked if a religious life that is highly syncretistic, a mixture of elements of Hinduism, Buddhism, and Islam. This is especially true in the city of Kraton Surakarta, where growing dozens of contemporary religious movements, called the movement psychotherapy. Regional palaces of Java is called Negarigung (Koentjaraningrat. 1984: 25). Javanese way of life cannot be separated by the King's role and power in the palace. Given the position of the palace as the center of the 


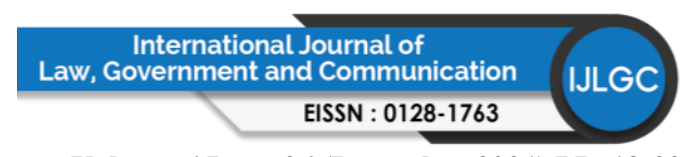

Volume 6 Issue 26 (December 2021) PP. 13-22 DOI 10.35631/IJLGC.626002

universe, then setting the buildings within the palace cannot be separated from efforts to harmonize the king's palace to the community life of the universe it. Position King cannot be separated from the power of the authorities, to do it is with spiritual concepts that may be due to cultural influence from India (Darsiti, 1989: 3). Traditional culture is no longer a social status symbol, to anyone who could took away her economically, socially, and intellectually can be part of high culture. There are also new patterns of professionalism to the traditional arts. Apprenticeship in artistic inheritance pattern is replaced with the institutions of art. Formalism old palace of culture was replaced by formalism plural of the institutions of art (Kuntowijoyo, 1987: 29).

Java community is not a collection of individual human beings connecting with one another as well as individual the one with lie community, but a unity that bound between each other by the norms of life-based religion. The tradition as well as a community foundation that is mutual cooperation. The system of family life in Java reflected in customary law. As the smallest unit society is the family life. A family can live together in the community to create the life of the most little-known village communities. Several hundred villages which are geographically incorporated in an area, such as Surakarta, turns each have a social life norms are different. Therefore, people who live in these areas is a family community called regional community (Badiono Herusatoto, 1991:42).

Architecture Java House is determined by the culture and attitude of the human life of Java. Therefore, in the embodiment. Java House is a home that reflects the welfare of the world. In principle, Java House is a house that refers So the environment, the religious environment, family environment and socio -cultural environment. This is because the Java house moved from the concept of tradition that exists is that the human being is one the element of natural world, so humans should fee united with God. Man cannot be separated from nature, man must unite with nature, and human beings must also be united with his Lord. Thus, the purpose of life is to follow nature, enhance and maintain the natural realm to the welfare of the world. Java house consists of a wide variety of physical forms architectural, among others: Joglo, Tajug,

Limasan, kampung and Panggang-Pe, Joglo is one of the few forms of Java House. Joglo has a different shape and form the most perfect among other forms of Java House. Compared with other Java area, the form Joglo growing in the region of Surakarta has a specific character. In terms of the shape and structure of the building. Joglo is a building that has a high value concept, in most of title Java community, Joglo building functioned as Pendhapa. Physical form Joglo as building Pendapa, in addition to paying attention to the aesthetic values, are also bound by the cultural values prevailing in the Java community, such as the system layout always refers to the non-physical aspects that customs and beliefs that they profess . Therefore, Joglo as Pendhapa buildings can blend with the natural environment and culture of the people. Uniqueness always appear on the building Joglo, as well as symmetrical shapes that symbolize balance awl all formal-an, roof towering malambangtan charismatic nature and the authority, has four Saka Guru who symbolizes strength or robustness and power, have a look-fence different side-rear symbolizes less open attitude and a south-feeing building that symbolizes the populist (protector of the little people) .Most traditional buildings, has charts arrangements which are often based on things that are holy or sacred, because religion and ritual is the center. 


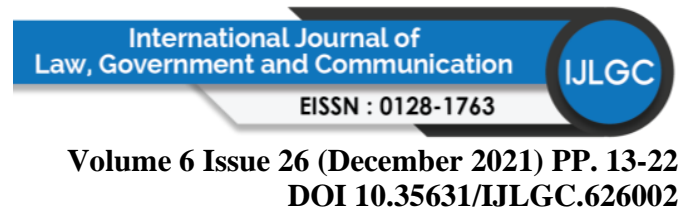

This is because the traditional view of society is religious (Rapopot, 1979 Wondoamiseno, 1991:7). Similarly, the traditional houses of Indonesia cannot be separated from the values of sanctity and also often has value as a type or symbol For example: Java House, the symbol of the sanctity centered in the middle senthong (krobongan/pasren/petanen), homage is addressed to Dewi Sri as a protective emblem of fertility or a bride who will forward the human generations. Dewi Sri denoted as rice seeds to be planted back in. While the statue Loro blonyo generally placed in front of this symbol Krobongan. By expected, the occupants will get a sense of ease and happy in her house. Thus, a sense of ease and happy in the house one of the background purposes Javanese life. Besides home symmetrical shape or alignment represents the balance to be achieved in life. In Traditional Javanese house, Pendhapa often called front home and serves as a living room. Pendhapa often also called open room or public room. However, in its development Pendhapa can function as a social communication space or can also called as a social communication media. It is associated with the development of the culture and lifestyle of the people in the open society.

Today the form and the function of pendhapa has be changed. Pendhapa is not symbol of aristocratic people. The ruler has build the pendhapa style in the front of their office in order to serve the people and as open space for the people. It is as the logic impact of democratic era. The rules are not from the king's family again, but from the common people.

\section{Conclusion}

Based on the description of the form and function Pendhapa. The authors can conclude the following: Java community in Surakarta is the Java community that has a view of life which can not be separated by the king's role and power in Keraton. Pendhapa growing in Sarakarta, most have the characteristic form of Joglo. Joglo square form and has four main pillars called Saka Guru. The four pillars support the roof towering in the middle, and the roof is called roof Branjung. Pendhapa in Java House serves as a gathering place, deliberation and social interaction between citizens. While in development, function pendhapa shifted into a public space for commercial purposes. Pendhapa can function as a social communication space or can also called as a social communication media. There are changed in the form and function of Javanese pendhapa dua of the democratic era.. The king has not have a superior power yet.

\section{References}

Arguelles, Miriam and Jose, 1972, Mandala, Shambhala, Boulder and London BrownManrique,

Budhisantoso,S, 1984, Identitas Budaya dalam Karya Arsitektur, Simposium arsitektur, Jakarta.

Budihardjo, Eko, 1997, Arsitek dan Arsitektur Indonesia: Menyongsong Masa Depan, ANDI, Yogyakarta.

Carey, Peter, 1986, Ekologi Kebudayaan Jawa \& Kitab Kedung Kebo , Pustaka Azet, Jakarta. Ching,

Departemen Pendidikan dan Kebudayaan, 1985, Arsitektur Tradisional Daerah Jawa Tengah, Proyek Inventarisasi dan Dokumentasi Kebudayaan Daerah Jawa Tengah, Semarang.

Dickie, George, et al, Aesthetics - A Critical Anthology, St. Martins Press, New York, 1989. 


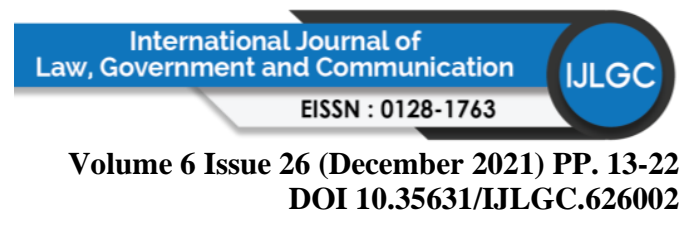

Doczi, Gyorgy, 1981, The Power of Limits: Proportional Harmonies in Nature, Art and Architecture, Shambala, Boston \& London.

Fischer, Joseph, 1994, The Folk Art of Java, Oxford University Press, Oxford.

Francis DK, 1979, Architecture: Form, Space \& Order, Van Nostrand Reinhold Comp, New York.

Frutiger, Adrian, 1989, Signs and Symbols: Their Design and Meaning, Weiss Verlag $\mathrm{GmbH}$, West Germany.

Geertz, C, 1960, The Religion of Java, The University of Chicago Press, USA.

Gerardo, 1978, Morphology and Evolution : The Architecture of O.Mathias Ungers, Unpublished Paper.

Hamzuri, Rumah Tradisional Jawa, Proyek Pengembangan Permuseuman DKI Jakarta.

Hardjowirogo, Marbangun, 1980, Adat Istiadat Jawa, Padma , Bandung.

Herusatoto, Budiono, 1991, Simbolisme dalam Budaya Jawa, PT. Hanindita, Yogyakarta.

Ihromi, T. 1987, Kebudayaan Mentalitas dan Pembangunan, PT. Gramedia, Jakarta.

Ihromi, T. 1993, Manusia dan Kebudayaan Di Indonesia, Djambatan, Jakarta.

Ismunandar, 1987, Joglo: Arsitektur Rumah Tradisional Jawa, Dahara Prize, Semarang.

Jencks, Charles, 1973, Modern Movements in Architecture, Anchor Books, Garden City, New York.

Kayam, Umar, 1980, Arsitektur dan Keseimbangan, Seminar Arsitektur, Bandung.

Ki Sura, 1995, Primbon Jawi, UD. Mayasari, Solo.

Koentjaraningrat,1984, Kebudayaan Jawa, Penerbit Balai Pustaka, Jakarta.

Kuntowijoyo, 1987, Budaya dan Masyarakat, PT. Tiara Wacana, Yogyakarta.

Langer, Sussane K, Problematika Seni, STSI, Bandung, 1993.

Lombard, Denys, 1996, Nusa Jawa; Silang Budaya, PT. Gramedia Pustaka Utama, Jakarta.

Magnis, Franz \& Suseno, 1985, Etika Jawa: Sebuah Analisis Falsafi tentang Kebijaksanaan Hidup Jawa, PT. Gramedia, Jakarta.

Mangunwijaya, YB, 1988, Wastu Citra: Pengantar ke Ilmu Budaya Bentuk Arsitektur, Sendi-sendi Filsafatnya beserta Contoh-contoh Praktis, PT. Gramedia, Jakarta.

Moedjanto, G, 1994, Konsep Kekuasaan Jawa: Penerapannya oleh Raja-raja Mataram, Kanisius, Yogyakarta.

Moertono, Soemarsaid, 1985, Negara dan Usaha Bina Negara Di Jawa Masa Lampau: Studi tentang Masa Mataram II, Abad VII sampai XIX, Yayasan Obor Indonesia, Jakarta.

Moleong, Lexy J., 2001, Metodologi Penelitian Kualitatif, PT. Remaja Rosdakarya, Bandung. Moneo, Raphael, 1978, On Typology, Oppositions, MIT Press.

Muhadjir, Noeng, 2000, Metodologi Penelitian Kualitatif, Penerbit Rake Sarasin, Yogyakarta. Mulder, Niels, 1996, Pribadi Masyarakat Jawa, Pustaka Sinar Harapan, Jakarta.

Palladio,Andrea, 1965, The Four Books of Architecture, Dover Publications, New York.

Prijotomo, Josef, !992, Ideas and Forms of Javanese Architecture, Gajah Mada University Press, Yogyakarta.

Ronald, Arya, 1990, Ciri-ciri Karya Budaya Di Balik Tabir Keagungan Rumah Jawa, Universitas Atma Jaya, Yogyakarta.

Sachari, Agus \& Sunarya, Yan Yan, 2001, Desain dan Dunia Kesenirupaan Indonesia dalam Wacana Transformasi Budaya, Penerbit ITB, Bandung. 


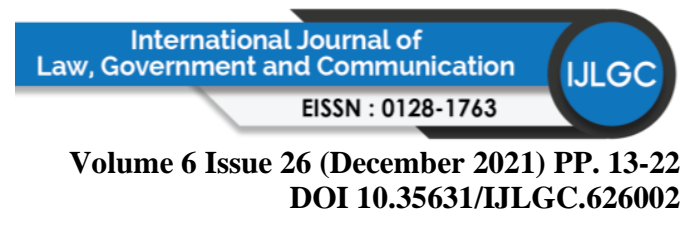

Sahman, Humar, 1993, Estetika-Telaah Sistemik dan Historik, IKIP Semarang Press. Sajid, RM, 1984, Babad Sala, Reksa Pustaka Mangkunegaran, Surakarta.

Sidharta \& Budihardjo, Eko, Konservasi Lingkungan dan Bangunan Kuno Bersejarah Di Surakarta, Gadjah Mada University Press, Yogyakarta.

Snyder, James C \& Catanese, Anthony J, 1979, Introduction to Architecture, McGrawHill Book Company, New York.

Soeroto, Myrtha, 2003, Dari Arsitektur Tradisional Menuju Arsitektur Indonesia, Ghalia Indonesia, Jakarta.

Stevens, Garry, 1990, The Reasoning Architect: Mathematics and Science in Design, McGraw-Hill Publishing Company, New York.

Sukarno, 1987, Ragam Hias Tradisional Jawa, Makalah, Lembaga Javanologi, Yogyakarta. Sukada,Budi.A, 1991, Memahami Arsitektur Tradisional dengan Pendekatan Tipologi, Simposium Arsitektur, Jakarta.

Sularto, Robi, 1981, Peranan Arsitektur Tradisional, Simposium IAI, Jakarta.

Sumardjan,Hindro,T, 1991, Arsitektur dan Kebudayaan, Seminar Asitektur, Jakarta.

Sumardjo, Jacob, 2000, Filsafat Seni, Penerbit ITB, Bandung.2003, Simbol-simbol Artefak Budaya Sunda, Kelir, Bandung.

Sumintardja, Djauhari, 1981, Kompendium Sejarah Arsitektur, Yayasan LPMB, Bandung.

Sutedjo, Suwondo B, 1985, Pencerminan Nilai Budaya dalam Arsitektur Di Indonesia Djambatan, Jakarta.

Tillman, Frank A \& Steven M. Cahn, Philosophy of Art and Aesthetics, Harper \& Row Publishers, New York, 1969.

Van de Ven, Cornelis, 1987, Space in Architecture terjemahan Ruang dalam Arsitektur, Van Gorcum \& Company, Nederland.

Vidler, Anthony, 1976, The Third Typology, Oppisitions, MIT Press.

Vitruvius, 1960, The Ten Books of Architecture, Dover Publications, New York.

Wiryomartono, A. Bagoes P, Seni Bangunan dan Seni Bina Kota Di Indonesia, PT. Gramedia Pustaka Utama, Jakarta.

Wittkower, 1973, Architecture Principles in The Age of Humanism, Academi Edition, London. Yosodipuro, KRMH, 1993, Falsafah yang Melandasi Ragam Hias yang terdapat pada Keraton Surakarta dan Yogyakarta 